Article

\title{
Nutrient Recapture from Insect Farm Waste: Bioconversion with Hermetia illucens (L.) (Diptera: Stratiomyidae)
}

\author{
Costanza Jucker ${ }^{1, *}$, Daniela Lupi ${ }^{1}$, Christopher Douglas Moore ${ }^{2,3,4}$, Maria Giovanna Leonardi ${ }^{1}$ \\ and Sara Savoldelli ${ }^{1}$ \\ 1 Department of Department of Food, Environmental and Nutritional Sciences, University of Milan, \\ Via Celoria 2, 20133 Milan, Italy; daniela.lupi@unimi.it (D.L.); mgiovanna.leonardi@unimi.it (M.G.L.); \\ sara.savoldelli@unimi.it (S.S.) \\ 2 School of Biosciences, University of Nottingham, Sutton Bonington Campus, Loughborough, \\ Leicestershire LE12 5RD, UK; c.d.moore@stir.ac.uk \\ 3 Monkfield Nutrition Ltd., Arthur Rickwood Farm, Chatteris Road, Mepal, Ely CB6 2AZ, UK \\ 4 Biological and Environmental Sciences, University of Stirling, Stirling FK9 4LA, UK \\ * Correspondence: costanza.jucker@unimi.it; Tel.: +025-031-6745
}

Received: 26 November 2019; Accepted: 30 December 2019; Published: 2 January 2020

\begin{abstract}
Hermetia illucens is an efficient bioconverter able to grow on various different organic materials, producing larvae, which are a good source of protein and fat with applications in the animal feed and biochemical industries. This fly's capacity to reduce huge amounts of waste presents an interesting opportunity to establish a circular food economy. In this study, we assessed the suitability of using organic wastes from cricket and locust farming to rear $H$. illucens. Larvae developed until adult emergence on all the wastes, with a mean survival of over $94 \%$. Cricket waste allowed faster development of heavier larvae than locust waste. Substrate reduction was particularly interesting on cricket waste $(<72 \%)$, while locust waste was only reduced by $33 \%$. The nutritional composition of the larvae reflected that of the growing substrates with a high protein and fat content. These results demonstrate the potential of using $H$. illucens to reduce and valorise waste generated when farming various insects through the production of a larval biomass for use as a protein meal in animal feeds or industrial applications.
\end{abstract}

Keywords: black soldier fly; waste reduction; larval performance; insect farming

\section{Introduction}

By 2050, the global population will have reached 9.6 billion. Growing wealth will allow rapidly growing middle classes to demand better living standards [1], which would be accompanied by increased meat consumption. Combined, these factors are expected to increase meat demand by 57\% by 2050 [2]. Currently, 78\% of agricultural land is used in the production of livestock as either grazing land (pasture or meadows, $68 \%$ ) or growing fodder (10\%) [3,4], and over $80 \%$ of new farm land has replaced forests [5]. It is therefore patently clear that meeting future food demands with current food production systems is unsustainable and that "business as usual" cannot continue without dire environmental consequences. Internal pressures within the food production system are also driving change. Protein feed prices are rapidly increasing due to rising demand for soybean and fish meal, while fishery productivity decreases. Having peaked in 1994, prices have risen from less than $\$ 1000$ per ton (2006), peaking at over $\$ 2000$ per ton after 2012 [6]. There is a severe need to address these issues to provide suitable, sustainable nutrition for the growing global population. One route currently being investigated as a partial solution for these issues is consuming insects, both directly and as animal feed. 
Insects appear highly suitable for integration into the human food chain based on their nutritional characteristics and life history [7]. The nutritional value of insects is comparable to meat [8,9] and better than plant sources, with higher digestibility, more balanced amino acid profiles, and high levels of polyunsaturated fatty acids $[10,11]$. Moreover, greenhouse gas emissions, such as methane, from insect production are low [12-14].

Numerous studies have shown that insects and insect meals can be used in pet food and livestock feed, in particular for fish and poultry [15-18]. Moreover, many insect species can convert inedible organic material with zero-value (byproducts, waste, organic side-streams) into high-protein feed that can replace expensive feed ingredients normally used for livestock (e.g., fish meal) $[15,19,20]$. Of particular interest for livestock feed applications are the larvae of generalist saprophytic fly species, such as the black soldier fly (Hermetia illucens L., Diptera: Stratiomyidae) and the house fly (Musca domestica L., Diptera: Muscidae). The larval stages of these species can convert inedible organic material of minimal value into valuable biomass, which presents an additional opportunity to reduce the 1.3 billion tons of food that is wasted annually [21-24]. In this study, we will focus on the black soldier fly (BSF), H. illucens, which can be used to bioconvert organic matter into insect biomass rich in crude protein $(42 \%)$ and fat $(29 \%)$ [23,25-27]. BSF has been intensively studied for applications in waste management, as it is able to accumulate nutrients from what is currently wasted, allowing the establishment of a circular, rather than linear, food economy $[18,28,29]$. BSF larvae have been used for decades in the pet food trade and have recently been approved as aquaculture feed in Europe, the United States, and Canada [30,31]. Moreover, researchers advocate additional industrial applications such as biofuel and pharmaceutical production [32-35].

Many insects suitable as human food, such as crickets and grasshoppers, have been farmed for over 50 years for use as feed for insectivorous pets and zoo animals. The European pet food market is the second largest in the world with an estimated value of U.S. \$21.5 billion [36] with about 8.59 million reptile and amphibian pets kept across Europe [37-39]. The production of these insects, despite normally being conducted on formulated diets, seems to be more efficient than rearing some traditional livestock $[7,40]$. However, a large quantity of organic waste is still produced during the mass rearing. This waste, consisting of frass, exuviae, and uneaten feed, is of little value and is commonly disposed of by spreading on agricultural fields (C.D. Moore, pers. obs.).

In this study, we investigated the suitability of using wastes coming from a farm rearing crickets and locusts as the growing substrate for H. illucens to improve the efficiency of insect farms and investigate the possibility of establishing a circular food economy. We assessed the impact of waste originating from cricket and grasshopper rearing on H. illucens performance in terms of growth, yield of larvae, and production of adults. We also evaluated the larval efficiency to consume and metabolize these substrates and the impact of the diet on the nutritional composition of the collected larvae.

\section{Materials and Methods}

\subsection{Source of Flies and Feeding Trials}

Newly hatched black soldier fly larvae were obtained from a colony previously founded at the University of Milan [25,41] and reared for 4 days on hen feed before experimental trials started.

Wastes from locusts (Schistocerca gregaria (Forskål)) and crickets (Gryllus bimaculatus (De Geer) and Gryllodes sigillatus (Walker)) production were provided by a commercial insect farm (Monkfield Nutrition Ltd., UK) from post-harvest rearing cages and tested as rearing substrates for H. illucens larvae. Locust waste consisted of frass, locust exuviae, dead locusts, uneaten brassicas, and uneaten feed (ForFarmers Fine Layers Meal). Cricket waste consisted of frass, exuviae, dead crickets, and uneaten feed (Marsden's Ultimate Superfine Crumb). Wastes were stored at $-18{ }^{\circ} \mathrm{C}$ for $>12 \mathrm{~h}$ before being transported to the University of Milan, Italy.

Feeding substrates were given to larvae as they were or chopped with a mixer to evaluate if a shredded diet could improve H. illucens performance. Water was added where necessary to reach a 
moisture content of $50-60 \%$. In addition, a standard diet containing $50 \%$ wheat germ, $30 \%$ alfalfa, and $20 \%$ corn flour added with water (moisture content $60 \%$ ) was used as a control. To summarize, the following rearing substrates were tested: (1) Cricket waste; (2) chopped cricket waste; (3) locust waste; (4) chopped locust waste; (5) standard diet.

\subsubsection{Larval Growth and Waste Reduction Efficiency}

For each substrate, 200 4-day-old larvae were placed in a plastic container (500 mL) with a perforated lid lined with mesh netting. Three replicates per substrate were prepared and food was provided ad libitum until $40 \%$ of the samples in each replicate reached prepupal stage, indicated by the characteristic colour change from white to dark cream. Containers were maintained in a climate chamber (T $25^{\circ} \pm 0.5^{\circ} \mathrm{C}$; RH $60 \pm 0.5 \%$; light cycle 12:12 L:D). During the growth phase, ten larvae from each replicate were removed every three days to be weighted with an analytical balance (SartoriusCP64, Germany) before returning to the container from which they were collected.

To determine the waste reduction index (WRI) and the efficiency of the conversion of the substrates into valuable biomass (efficiency of conversion of the ingested food $=\mathrm{ECI}$ ), the total amount of food added, the substrate remaining at the end of the experiment, and the final biomass (larvae and pupae) were weighed. All indexes were calculated on dry matter. Indexes were calculated as follows:

- $\quad$ WRI (waste reduction index $)=(\mathrm{W}-\mathrm{R} / \mathrm{W}) /$ days of trial $(\mathrm{d}) \times 100$

where $\mathrm{W}=$ total amount of feed provided; $\mathrm{R}$ = remaining substrate

- $\quad \mathrm{ECI}$ (efficiency of conversion of the ingested food) $=\mathrm{B} /(\mathrm{W}-\mathrm{R})$

where $\mathrm{B}=$ total biomass (larvae + pupae) (g); $\mathrm{W}=$ total amount of feed provided; $\mathrm{R}=$ remaining substrate

- $\quad \mathrm{SR}$ (substrate reduction) $=\mathrm{W}-\mathrm{R} / \mathrm{W}^{*} 100$

where $\mathrm{W}=$ total amount of feed provided; $\mathrm{R}$ = remaining substrate

Moreover, the larval daily growth rate was calculated as follows:

- $\mathrm{GR}($ Larval growth rate $(\mathrm{g} / \mathrm{d}))=($ final larval average weight - initial larval average weight $) /$ number of days of the trial [42].

\subsubsection{Pupae and Adults}

The presence of pupae was checked daily and, when found, they were counted and transferred in a separate lidded container. Fifty pupae for each replicate (150 per experimental treatment) were weighed. Wood shavings were added to each container in order to facilitate pupal development to emerge as adults. Larval and pupal mortality was registered. Moreover, emerged adults were sexed and the weight of 60 adults (thirty males and thirty females) for each replicate was acquired after desiccation to a constant weight.

\subsubsection{Chemical Analyses}

In order to have enough $H$. illucens larvae for chemical analyses, a separate set of 4-day-old larvae, previously fed on the hen diet, was reared to prepupae on the three experimental diets. All mature larvae were collected from each container and stored at $-18{ }^{\circ} \mathrm{C}$. Chemical analyses of the larvae and of the rearing substrates were conducted by the ARAL (Associazione Regionale Allevatori della Lombardia) Laboratory, Crema, Italy.

Chemical analyses were performed as follows: Dry weight was determined after drying the samples (substrates or larvae) at $103{ }^{\circ} \mathrm{C}$ using a Binder oven, while ash was established by complete combustion at $550{ }^{\circ} \mathrm{C}$ (REG CE 152/2009) (Passoni, Italy). Crude protein (CP) was determined by Kjeldahl Turboterm Vapodest Gerhardt (UNI EN ISO 5983-2:2009), while neutral detergent fibre (NDF) and acid detergent fibre (ADF) were determined using a FIBERTEC (Mod. 2010, FOSS; Danemark) following the Fibretec 2010 Auto Fiber Analysis System (Foss Analytical, ASN 3431 and ASN 3429, 
van Soest Method, AOAC 973.18). Finally, ether extract was determined by Twisselman Method (Reg. REG CE 152/2009) (Twisselman, WBV6, FALC, Treviglio (BG), Italy).

\subsection{Statistical Analyses}

Data recorded on time of larval development, final larval and pupal weight, adult weight and length, survival of different stages, the waste reduction, and biomass production were compared by one-way ANOVA. To test significant differences, prior to analyses, all data were examined with Levene's test for homogeneity of variance and with the Shapiro Wilk test for normal distribution. Where significant differences occurred, the Tukey-Kramer honestly significant difference (HSD) multiple comparisons test was applied for mean separation $(p<0.05)$ between tested diets.

The two-tailed Student's $t$-test was used to determine significant differences between male and female weight and length $(p<0.05)$. The statistical analyses were performed by SPSS ${ }^{\circledR}$ Statistic (Version 23 for Windows, SPSS Inc. Chicago, IL, USA).

\section{Results}

\subsection{Chemical Composition of the Rearing Substrates}

Chemical composition of the experimental wastes and of the standard diet varied in their composition, as illustrated in Table 1. The initial moisture content of the diets was similar in the standard diet and cricket waste, while the locust waste showed a considerably higher water content $(52.87 \%)$. Locust waste showed the highest ash value (13.39\%) compared to the other substrates. Prior to larval feeding, water was added to drier substrates to obtain a moisture between 50 and $60 \%$. Crude protein content was lower in the standard diet (21.64\%) than the cricket and locust wastes $(>32 \%)$. Fat content also varied within rearing substrates from $3.17 \%$ (cricket waste) to $8.38 \%$ (locust waste). NDF (neutral detergent fibre) and ADF (acid detergent fibre) were higher in locust waste, followed by standard diet and cricket waste. Locust waste showed a lower NFC (9.7\%) (nonfibre carbohydrates) content than the other substrates $(>30 \%)$.

Table 1. Chemical composition of the different substrates used for Hermetia illucens larvae rearing, before adding water. (Values are reported on dry matter, except for moisture content) (g/100 g).

\begin{tabular}{cccc}
\hline Chemical Composition & Cricket Waste & Locust Waste & Standard Diet \\
\hline Moisture content (\%) & 10.93 & 52.87 & 9.29 \\
Ash (\%) & 10.30 & 13.39 & 6.62 \\
Crude protein (\%) & 32.60 & 41.75 & 21.64 \\
Crude fat (\%) & 3.17 & 8.38 & 6.05 \\
Neutral detergent fibre (NDF) (\%) & 23.31 & 27.15 & 26.15 \\
Acid detergent fibre (ADF) (\%) & 12.69 & 18.94 & 15.76 \\
Nonfibre carbohydrates (NFC) & 31.03 & 9.70 & 39.82 \\
\hline
\end{tabular}

\subsection{Chemical Composition of the BSF Larvae}

Table 2 reports the chemical composition of $H$. illucens larvae grown on the different rearing diets. Ash content of BSF larvae replicated the content of the rearing substrates: lower in larvae grown on standard diet and higher in those on locust waste. Protein content of the larvae grown on the locust waste was the highest (CP $49.18 \%$ ), followed by larvae fed with standard diet and cricket waste (CP $46.07 \%$ and $37.06 \%$, respectively). Fat varied from a minimum of $25.83 \%$ in larvae grown on locust waste to a maximum of $38.67 \%$ in larvae on cricket waste. Saturated fatty acids were always higher than the unsaturated, and this was particularly the case for larvae reared on cricket waste. Moreover, while the polyunsaturated fatty acid content of larvae reared on locust waste was higher than monounsaturated fatty acids, in the other larval groups, the opposite situation was observed. 
NDF was similar across treatments, varying from 13.38 to $15.86 \%$. Lastly, ADF was lower in larvae from cricket waste and higher in larvae from standard diet.

Table 2. Composition of $H$. illucens larvae on the different rearing substrates $(\mathrm{g} / 100 \mathrm{~g})$ (values are reported on dry matter).

\begin{tabular}{cccc}
\hline Chemical Composition/Nutrients & Cricket Waste & Locust Waste & Standard Diet \\
\hline Dry matter (\%) & 37.38 & 33.18 & 37.6 \\
Ash (\%) & 9.37 & 13.16 & 8.12 \\
Crude protein (\%) & 37.06 & 49.18 & 46.07 \\
Crude fat & 38.67 & 25.83 & 37.36 \\
Saturated fatty acids & 74.68 & 57.48 & 60.17 \\
Unsaturated fatty acids & 25.36 & 42.57 & 30.07 \\
Monounsaturated fatty acids & 13.40 & 19.49 & 21.65 \\
Polyunsaturated fatty acids & 11.96 & 23.08 & 8.42 \\
Neutral detergent fibre (NDF) & 13.38 & 15.86 & 13.96 \\
Acid detergent fibre (ADF) & 7.15 & 9.31 & 12.00 \\
\hline
\end{tabular}

\subsection{Larval Growth and Adult Performance}

Larvae successfully developed on all the tested substrates, with larval growth on the chopped locust waste diet significantly slower than on all other diets $\left(\mathrm{F}_{4,10}=18.28 ; p<0.05\right)$, and a mean of $21.3 \pm 1.22$ days necessary to reach the prepupal stage (Figures 1 and 2). Nonchopped locust waste gave intermediate results. Larvae reared on other substrates took less time to pupate; in particular, larvae on cricket waste (as is or chopped) gave the same results as the control diet, with a mean of 16 days for $40 \%$ of larvae to develop to prepupae. Rearing substrate also had a significant influence on final larval weight (Figure 3; $F_{4,10}=23.07, p<0.05$ ). The highest final larval weight was achieved in larvae reared on cricket waste and standard diet, which statistically differed from the larvae grown on locust waste (Figure 3). Chopping the rearing substrate did not result in increased larval weight.

BSF growth patterns were similar across growing substrates (Figure 4). Larvae consistently gained weight until they stopped feeding prior to entering the prepupal stage.

Pupal weight was also influenced by feeding substrates $\left(\mathrm{F}_{4,475}=115.56 ; p<0.05\right)$, reflecting the trends of larval weight: heaviest pupae were reared on the standard and cricket waste diets, while the lightest were reared on locust waste (either as is or chopped) (Figure 3).

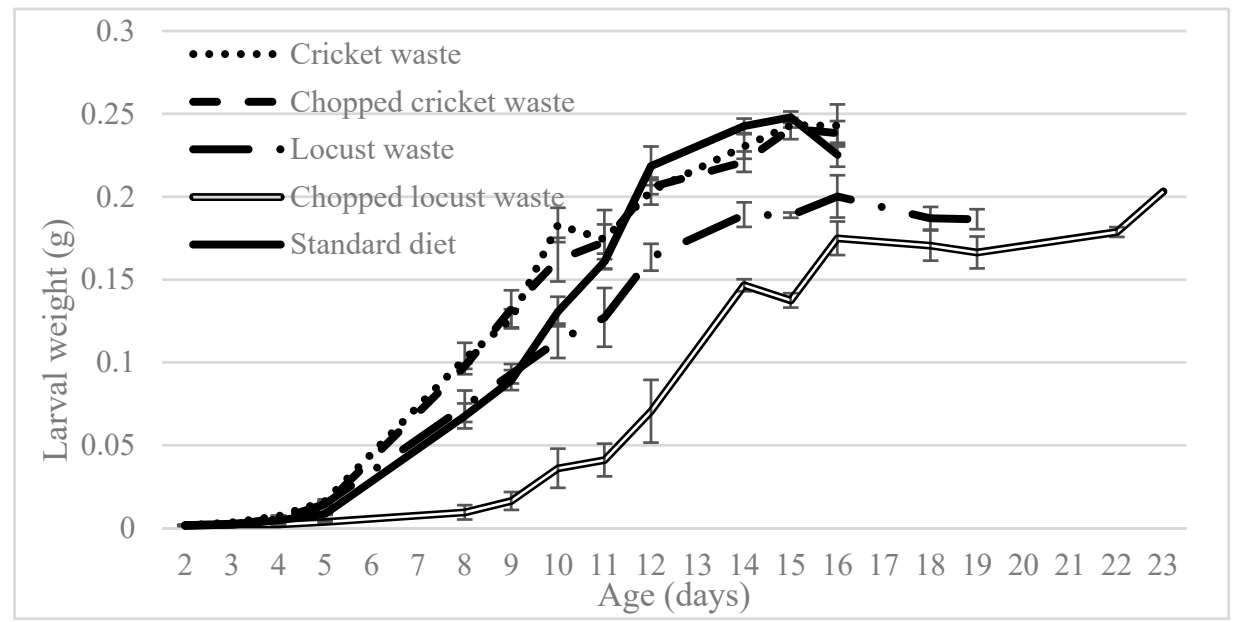

Figure 1. Trend of larval growth on the different experimental diets. 


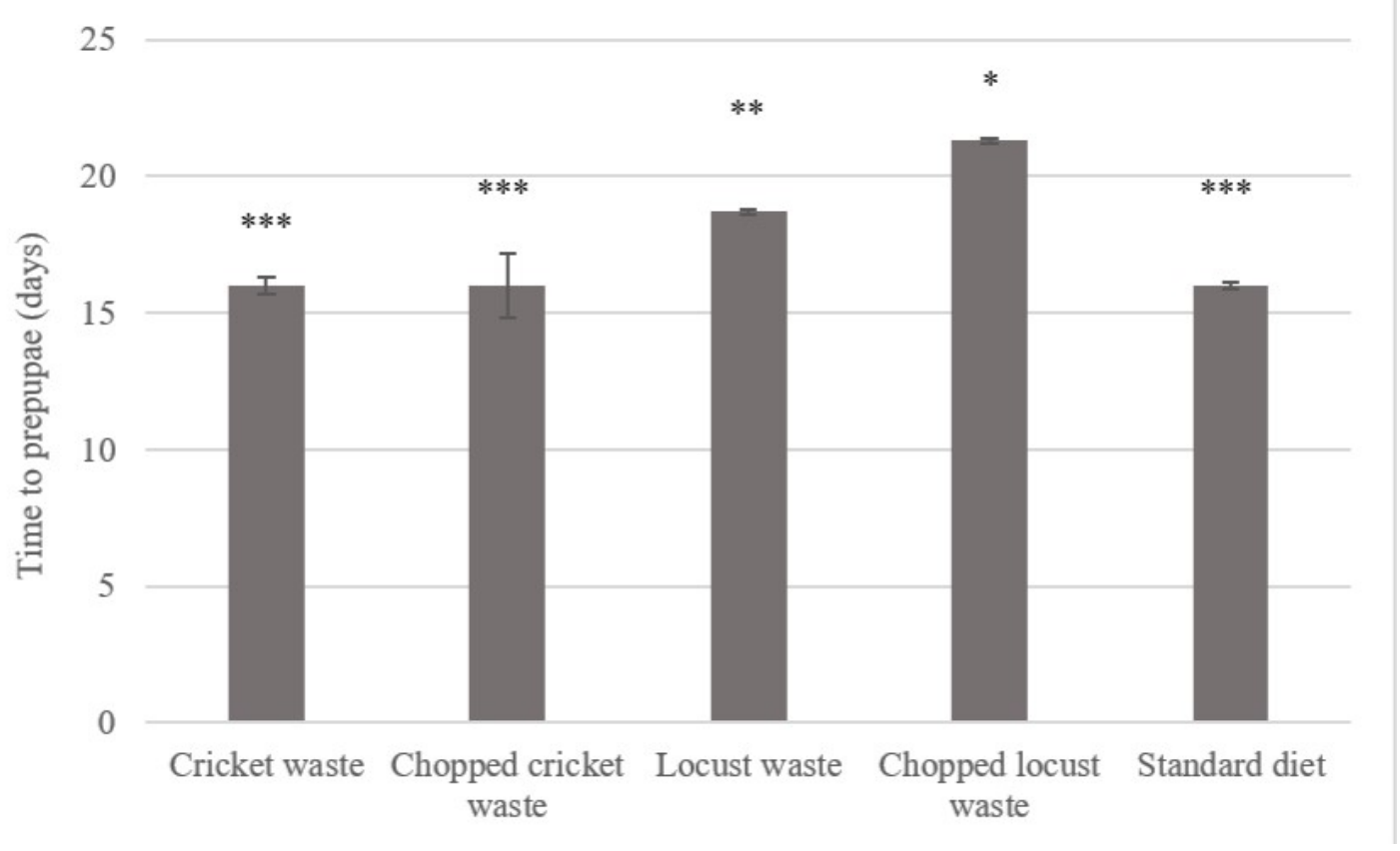

Figure 2. Days to reach the prepupal stage.

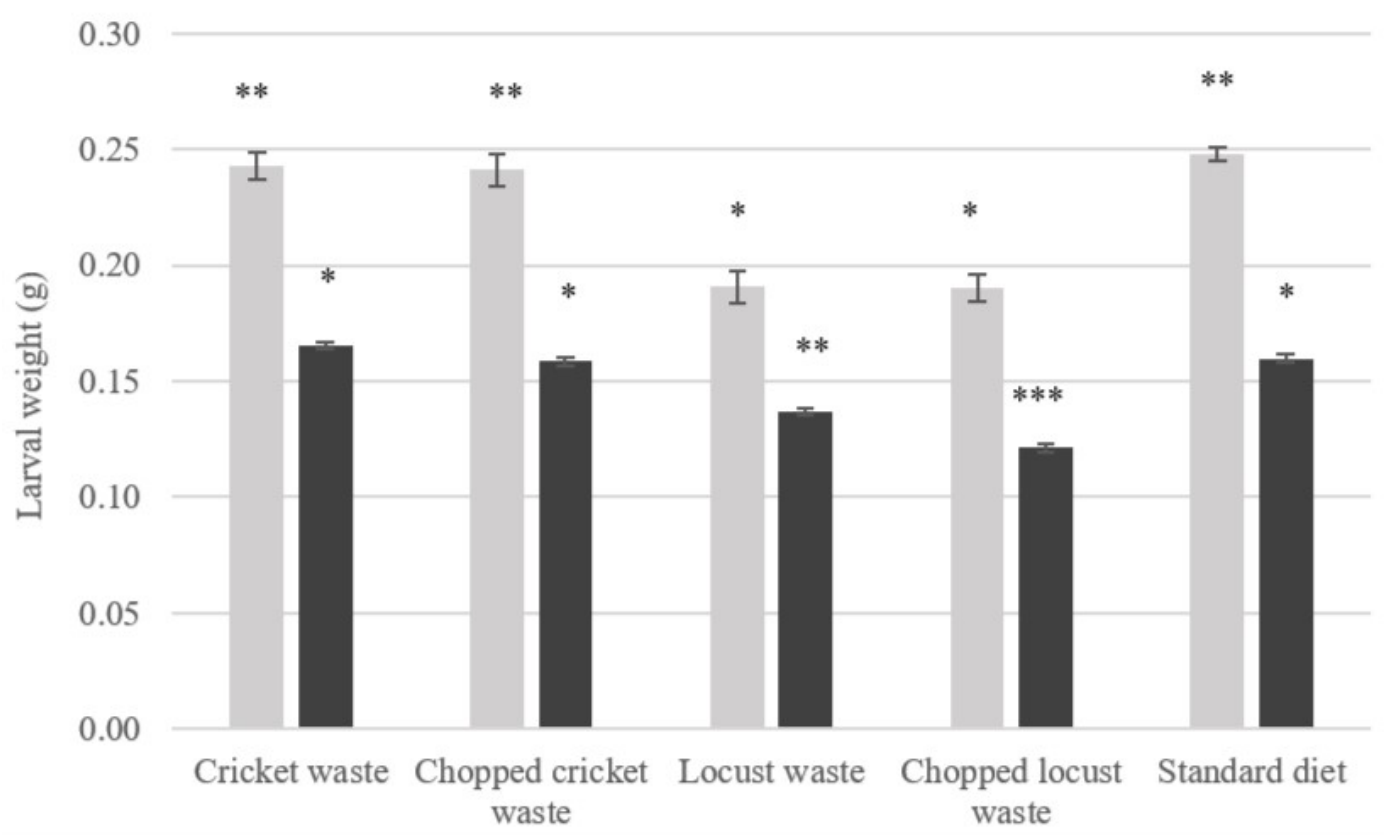

Figure 3. Prepupal (light grey) and pupal (black) weight reached from H. illucens on the different rearing substrates. Asterisks refer to significant differences among the rearing substrates within the same stage group. 


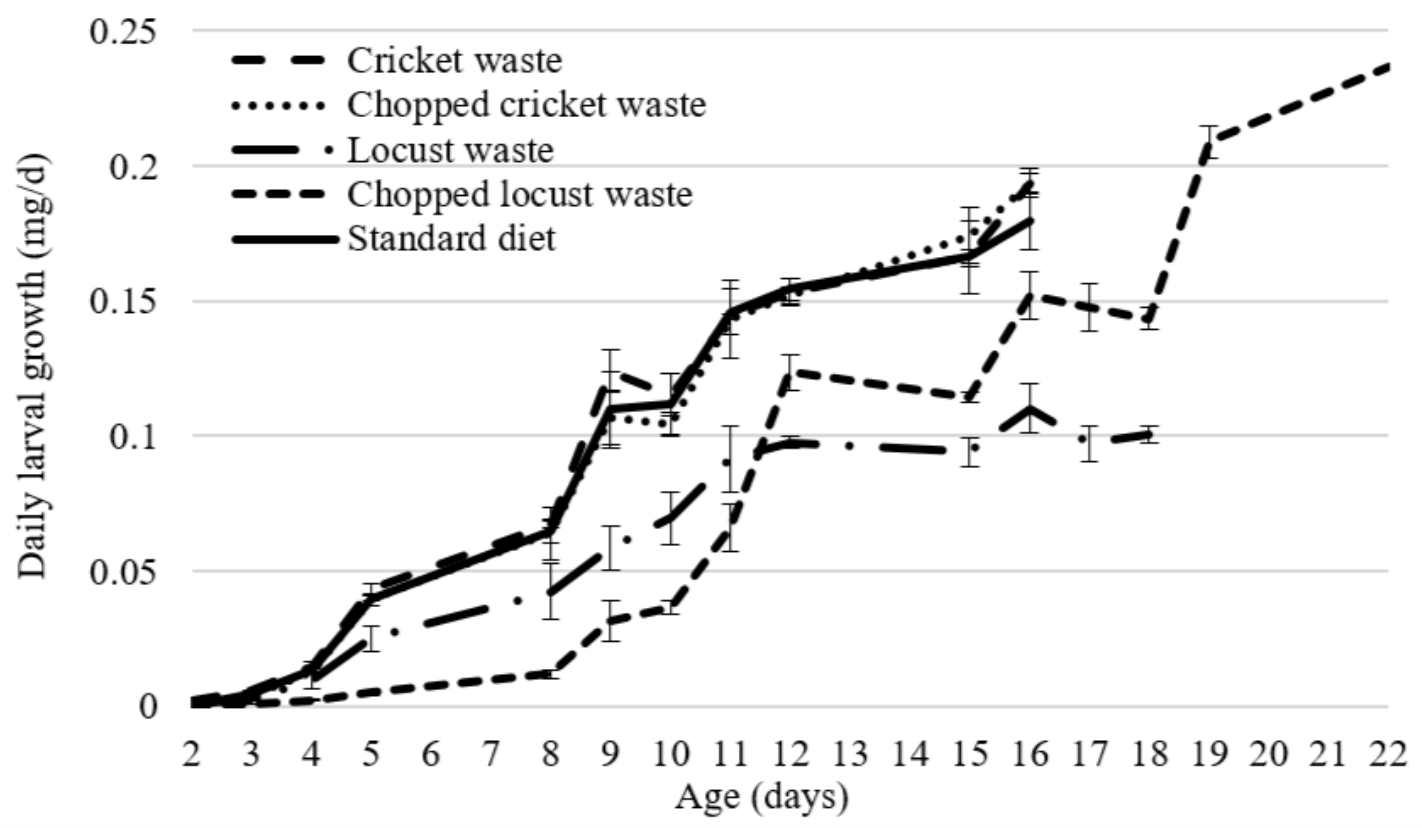

Figure 4. Trend of the daily larval growth.

The weight and length of adults of the same sex varied significantly with diet (male length: $\mathrm{F}_{4,295}=58.78 ; p<0.05$; female length: $\mathrm{F}_{4,295}=71.15 ; p<0.05$; male weight: $\mathrm{F}_{4,295}=438.9 ; p<0.05$; female weight: $F_{4,295}=202.59 ; p<0.05$ ) (Table 3). Males and females that emerged from larvae grown on both locust diets were always lighter and smaller than adults of the other experimental diets (Table 3). Within the same diet, significant differences between sex were observed only in the weight of adults that emerged from cricket diet and standard diet, where females were significantly heavier than males $(p<0.05)$.

Table 3. Length and weight of adults that emerged from the experimental substrates (adult weight referred to dry weight).

\begin{tabular}{ccccc}
\hline Diet & \multicolumn{2}{c}{ Length (mm) } & \multicolumn{2}{c}{ Weight (mg) } \\
\hline & Males & Females & Males & Females \\
\hline Cricket waste & $15.78 \pm 0.10 \mathrm{Acd}$ & $15.60 \pm 0.10 \mathrm{Acd}$ & $30.4 \pm 0.29 \mathrm{Ad}$ & $35.8 \pm 0.68 \mathrm{Bd}$ \\
Chopped cricket waste & $15.44 \pm 0.11 \mathrm{Ac}$ & $15.46 \pm 0.10 \mathrm{Ac}$ & $26.3 \pm 0.28 \mathrm{Ac}$ & $34.4 \pm 0.25 \mathrm{Ad}$ \\
Locust waste & $14.64 \pm 0.092 \mathrm{Ab}$ & $14.43 \pm 0.083 \mathrm{Ab}$ & $19.8 \pm 0.33 \mathrm{Ab}$ & $23.9 \pm 0.31 \mathrm{Ab}$ \\
Chopped locust waste & $14.19 \pm 0.092 \mathrm{Aa}$ & $13.98 \pm 0.082 \mathrm{Aa}$ & $16.6 \pm 0.18 \mathrm{Aa}$ & $20.6 \pm 0.21 \mathrm{Aa}$ \\
Standard diet & $15.86 \pm 0.09 \mathrm{Ad}$ & $15.88 \pm 0.12 \mathrm{Ad}$ & $27.2 \pm 0.25 \mathrm{Ac}$ & $32.4 \pm 0.68 \mathrm{Bc}$ \\
\hline
\end{tabular}

Means \pm SE in males and females within the same treatment followed by the same capital letter do not differ significantly $(t$-test, $p<0.05)$. Values followed by the same lowercase letter in the same column are not statistically different $(p<0.05)$.

\subsection{Survival}

Survival was not significantly affected by the rearing substrates $(p>0.05)$. Mortality was very low in all the diets tested, and no statistical differences were observed on both larval and pupal survival $(p>0.05)$ (Figure 5). The mean percentage of larval survival from four-day larvae to prepupal stage was $94 \pm 15 \%$, with a minimum mean value of $88 \pm 2.85 \%$ observed in chopped locust waste and a maximum of $98 \pm 1 \%$ in chopped cricket waste. Pupae survival was even higher, with a total mean of $97 \pm 5.04 \%$. 


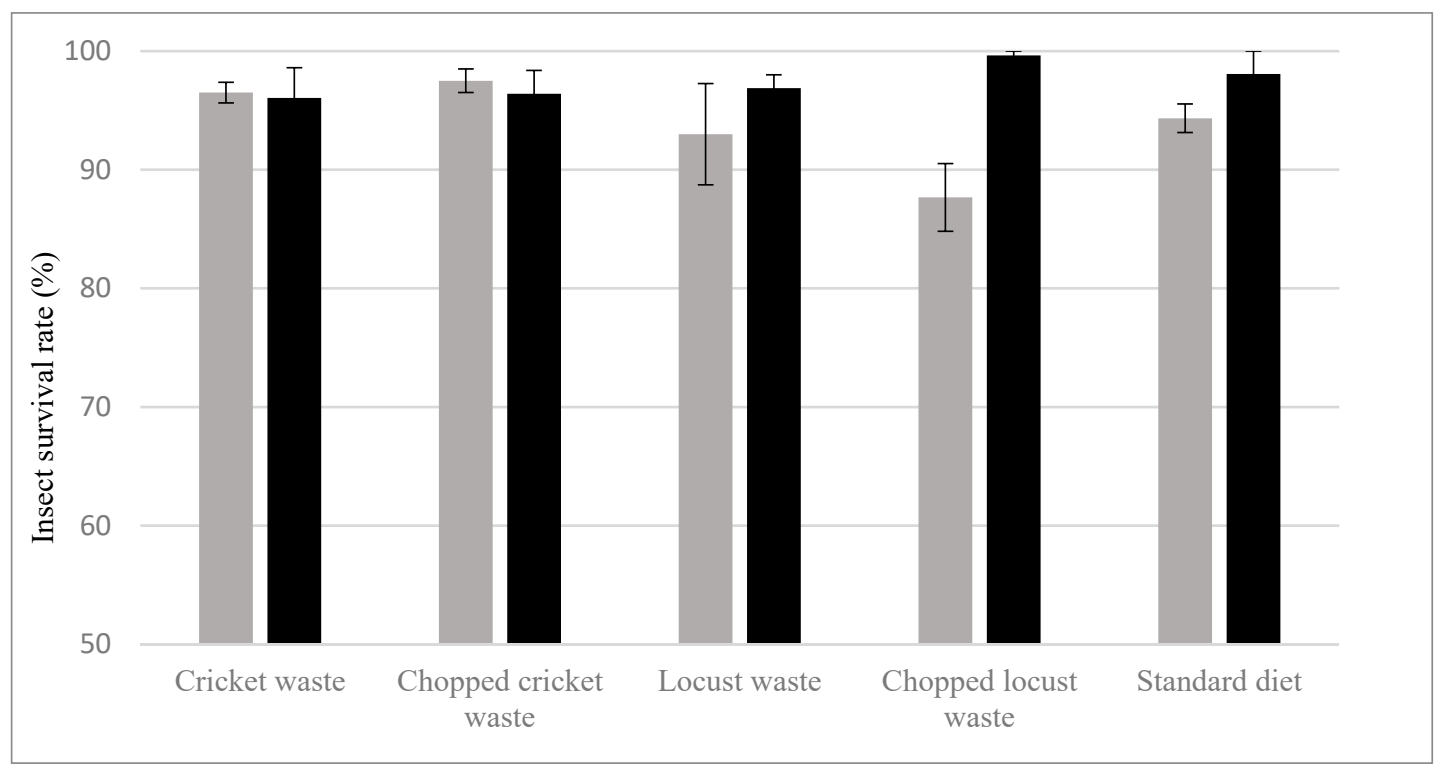

Figure 5. Larval (grey) and pupal (black) survival on the different experimental diets.

\subsection{Waste Reduction and Biomass Production}

The waste reduction and bioconversion of experimental substrates by BSF larvae differed significantly between experimental diets (WRI: $\mathrm{F}_{4,10}=32.16 ; p<0.05$; SR: $\mathrm{F}_{4,10}=21.35 ; p<0.05$; ECI: $\mathrm{F}_{4,10}=10.76 ; p<0.05$ ) (Table 4 ). WRI (waste reduction index) describes the larval ability to reduce feeding substrates; therefore, higher values show a greater ability to reduce the organic matter. Larvae were better able to reduce the standard and chopped cricket diets than all other substrates, while those grown on locust waste always significantly differed from the other experimental diets. Substrates reduction (SR) varied from 28 to $72 \%$ and, following the WRI indexes, was higher in standard diet and when cricket waste was given to the larvae finely chopped. On the contrary, chopping the locust waste did not result in an increase of the waste reduction. The mean value of the ECI was higher in larvae fed with locust waste. In particular, the best efficiency was found when locust waste was given chopped with a value of $0.470 \pm 0.09$. Standard diet and cricket wastes were not significantly different from each other, with lower values compared locust waste diets.

Table 4. Waste reduction index (WRI), substrates reduction (SR), and efficiency of conversion of the ingested food (ECI) indexes of $H$. illucens larvae grown on different experimental substrates.

\begin{tabular}{cccc}
\hline Diet & WRI (g/d) & SR (\%) & ECI \\
\hline Cricket waste & $3.12 \pm 0.53 \mathrm{~b}$ & $49.89 \pm 8.51 \mathrm{~b}$ & $0.19 \pm 0.05 \mathrm{ab}$ \\
Chopped cricket waste & $4.50 \pm 0.16 \mathrm{c}$ & $72.04 \pm 2.50 \mathrm{c}$ & $0.16 \pm 0.01 \mathrm{a}$ \\
Locust waste & $1.79 \pm 0.10 \mathrm{a}$ & $33.30 \pm 1.28 \mathrm{ab}$ & $0.40 \pm 0.02 \mathrm{bc}$ \\
Chopped locust waste & $1.32 \pm 0.17 \mathrm{a}$ & $28.42 \pm 4.60 \mathrm{a}$ & $0.47 \pm 0.09 \mathrm{c}$ \\
Standard diet & $4.54 \pm 0.02 \mathrm{c}$ & $72.64 \pm 0.31 \mathrm{c}$ & $0.13 \pm 0.01 \mathrm{a}$ \\
\hline
\end{tabular}

Values (means \pm SE) followed by the same letter in the same column are not statistically different $(p<0.05)$.

\section{Discussion}

Hermetia illucens larvae have been suggested to have an important role to play in the framework of the circular economy by recycling resources that are normally eliminated or that do not find a reallocation in the food chain $[18,43,44]$. Larvae of this fly can feed on a wide range of organic substrates characterized by a different content of nutrients producing high-rich protein feed for livestock $[16,31,45,46]$. Nowadays, E.U. regulations prohibit the use of insects in the food chain if they are grown on manure or waste of animal origin. Nevertheless, many papers have shown 
that the environmental impact of insect production is highly influenced by the insect rearing substrate $[43,44,47,48]$. Thus, the possibility to exploit different waste streams could lower the environmental impact of insect mass production compared to the feed currently used (mainly feed for poultry) as well as contributing to the waste management.

In this study, we investigated the feasibility of rearing BSF larvae on wastes generated from the mass rearing of two other insect species, G. assimilis and S. gregaria, used in pet nutrition and with particular interest as a protein source for humans. We assessed how different rearing substrates influenced the larval growth in terms of final larval weight reached and development time, and the efficacy in waste reduction and bioconversion. As already observed, growth parameters for both larvae and adults were greatly influenced by the composition of feed substrates $[22,25,41,49,50]$. All experimental substrates allowed larval growth and emergence of $H$. illucens adults. Larval survival was always very high, showing that all the experimented substrates could effectively sustain the complete development of the insect. Survival results were in line or higher with other research where H. illucens was reared on artificial diets (e.g., Tomberlin et al., 2002) [51] or on organic substrates derived from different waste streams or byproducts [20,25,43,52]. The percentage of adult emergence was above $96 \%$ in all the experimental conditions, which is comparable to other studies on artificial diet or hen feed $[50,53]$, but in contrast with other research conducted on diets of vegetal or animal origin $[25,49,51]$. Although the experimental substrates differed in chemical composition, no relevant differences were noticed in the larval development time, except on locust chopped waste where the larval growth was slower (up to seven days more). These data are comparable with the growing of H. illucens on different organic substrates as dairy manure and soybean curd residue, brewer's waste or vegetable residue diets $[20,26,45,54]$. The rapid growth normally can be attributed to the high protein content of the different rearing substrates and the low fat content; in fact, a high fat content could be detrimental for black soldier fly larvae [22]. The longer growth on locust waste could be thus attributed to the higher lipid content of this substrate compared to the others. Nevertheless, this is in contrast with what was observed by Oonincx et al. (2015) [55], that is, a fastest development and higher survival rate when larvae are reared on high protein and fat diet, as in this case.

As shown in the growth curves (Figure 1), H. illucens larvae reached a significantly higher weight in fewer days when reared on cricket waste. The larval biomass gained differed among the substrates. In particular, the weight observed in larvae grown on cricket waste was the highest and comparable, for example, to what was observed by Tschimer and Simon (2015) [19], rearing H. illucens on dried distiller and beet pulp. Many other studies showed lower weight of larvae when reared on waste streams, of either animal or vegetal origin $[22,25,54]$. Adult dimension (weight and length) strongly reflected the trend of the weight of the preimaginal instars. In fact, it is known that H. illucens accumulates its fat body only during the larval stage, while adult nourishment is less important and mostly influences longevity $[41,51,56]$. As is typical in Diptera, adult females always weighed more than males [57,58].

$H$. illucens larvae were able to successfully consume cricket and locust organic waste, confirming their ability to bioconvert wide organic side-streams. The ability of the larvae to reduce the given substrate varied from 28 to $72 \%$. Cricket waste and the control diet showed the highest percentage in mass reduction, and data were similar to municipal waste [59] or on dairy manure and soybean curd residue [26]. Furthermore, Nyakeri et al. (2017) [60] found a substrate reduction from 44 to $81 \%$ on different organic waste substrates. The high value on cricket waste suggests the possibility of using $H$. illucens larvae to reduce the amount of such waste produced during the cricket rearing. Moreover, we observed that chopping the cricket substrate led to a higher substrate reduction, suggesting a major availability of the feed. On the contrary, the lectins content in brassicas, present in the locust waste, may have caused the lower substrate reduction observed in larvae on this waste. In fact, lectins are protease inhibitors that exert their toxic effect by binding to carbohydrates and glycol-proteins in the insect midgut, hence disrupting digestive processes and nutrient assimilation [61]. 
Food conversion efficiency shows the ability of the larvae to transform the ingested food into their biomass. Higher ECI index, found in locust waste, means a good efficiency in the conversion of the growing substrate into larval biomass. The lower food ingestion rate by larvae fed locust waste, as indicated by the low substrate reduction, probably suggests a slower passage of food in the larval gut that in turn causes a higher nutrient assimilation $[62,63]$.

The nutritional composition of the growing media is the main factor affecting the feed conversion efficiency of H. illucens. As already observed by Oonincx et al. (2015) [55], diets with high protein content results in higher conversion of the ingested substrate (ECI). Also in this study, the higher ECI index was observed on locust substrates where the protein content was higher than other growing substrates, showing that larvae are more efficient on this waste.

The chemical composition of the substrates also influenced the final proximate composition of the larvae. The experimental substrates assessed in this trail were characterized by considerably high protein content, which could have positively influenced the final protein level of the larvae. Indeed, protein content in mature larvae comprised between 37.06 and $49.18 \%$ dry matter in agreement with other studies $[20,64,65]$. Lipid content of H. illucens was also comparable to other studies, with the larger proportion consisting of saturated lipids $[55,65,66]$. The high fat content observed in larvae grown on cricket waste and standard diet are probably due to the high NFC levels found in these substrates [54]. In fact, protein and carbohydrates are needed by larvae for their growth (biomass production), and excessive dietary carbohydrates are converted into lipids, useful for pupae and adults, as confirmed by our research. In both cases, the final protein and fat content of the prepupae only partially reflected the content of the rearing substrates; however, as reported by Wang and Shelomi (2017) [27], a source of variation both for protein and lipid content could be observed among individuals and experimental boxes.

For an efficient insect mass-rearing facility, it is important to maximize the production of H. illucens larvae with lower costs in terms of materials and resources, making their production more competitive. Important goals are the achievement of an optimization between the survival, development time, and final weight reached by the larvae (biomass), and the nutritional properties [67]. Thus, research of an optimal growing substrate able to meet the nutrient requirement of the species is essential for an economical production. Although the results of the present study do not derive from an industrial producing process, they provide important information on the use of alternative rearing substrates. Considering the positive results obtained in terms of final larval weight, the high survival, and the fast development, we can speculate that the tested substrates can constitute a valuable rearing substrate for H. illucens mass rearing.

More studies are necessary to assess the potential microbial contamination and, in general, the food safety risks linked to the use of this insect-waste as feed for H. illucens larvae. Finally, the waste considered in this study has no secondary reuse, and thus, its exploitation as a rearing substrate for H. illucens offers economic and environmental benefits for sustainable management of organic wastes.

Author Contributions: Conceptualization and design research: C.J., S.S., D.L., C.D.M., M.G.L.; Methodology: C.J., S.S.; Investigation: C.J., S.S., M.G.L.; Data curation: C.J., S.S., D.L.; Writing-review and editing: C.J., C.D.M., M.G.L., S.S., D.L.; Project funding: C.J. All authors have read and agreed to the published version of the manuscript.

Funding: This research was funded by the University of Milan (Project EXPAND and PROENTO) and by the Knowledge Transfer Partnership programme (KTP) funded by U.K. Research and Innovation through Innovate U.K., part of the U.K. government's Industrial Strategy.

Acknowledgments: The authors would like to thank Marco Palamara for his contribution in the experimental trials.

Conflicts of Interest: The authors declare no conflict of interest. 


\section{References}

1. United Nations, Department of Economic and Social Affairs, Population Division. World Population Prospects: The 2012 Revision, Highlights and Advance Tables; Working Paper No. ESA/P/WP.228; Department of Economic and Social Affairs, Population Division: New York, NY, USA, 2013.

2. Alexandratos, N.; Bruinsma, J. World Agriculture Towards 2030/2050: The 2012 Revision; ESA Working paper No. 12-03; FAO: Rome, Italy, 2012.

3. FAO Stat. Land Use Indicators. Available online: http://www.fao.org/faostat (accessed on 18 July 2019).

4. Steinfeld, H.; Gerber, P.; Wassenaar, T.; Castel, V.; Rosales, M.; De Haan, C. Livestock's Long Shadow: Environmental Issues and Options; Food and Agriculture Organization of the United Nations (FAO): Rome, Italy, 2006.

5. Gibbs, H.K.; Ruesch, A.S.; Achard, F.; Clayton, M.K.; Holmgren, P.; Ramankutty, N.; Foley, J.A. Tropical forests were the primary sources of new agricultural land in the 1980s and 1990s. Proc. Natl. Acad. Sci. USA 2010, 107, 16732-16737. [CrossRef] [PubMed]

6. Soybean Meal Monthly Price. Available online: https://www.indexmundi.com/commodities/?commodity= soybean-meal\&months=360 (accessed on 25 July 2019).

7. Van Huis, A. Potential of insects as food and feed in assuring food security. Annu. Rev. Entomol. 2013, 58, 563-583. [CrossRef] [PubMed]

8. Van Huis, A.; Van Itterbeeck, J.; Klunder, H.; Mertens, E.; Halloran, A.; Muir, G.; Vantomme, P. Edible Insects: Future Prospects for Food and Feed Security; Forestry Paper 171; FAO: Rome, Italy, 2013.

9. Payne, C.L.R.; Scarborough, P.; Rayner, M.; Nonaka, K. Are edible insects more or less 'healthy' than commonly consumed meats? A comparison using two nutrient profiling models developed to combat overand undernutrition. Eur. J. Clin. Nutr. 2016, 70, 285-291. [CrossRef] [PubMed]

10. Ramos-Elorduy, J.; Moreno, J.M.P.; Camacho, V.H.M. Could Grasshoppers Be a Nutritive Meal? Food Nutr. Sci. 2012, 3, 12.

11. Zielińska, E.; Baraniak, B.; Karaś, M.; Rybczyńska, K.; Jakubczyk, A. Selected species of edible insects as a source of nutrient composition. Food Res. Int. 2015, 77, 460-466. [CrossRef]

12. Oonincx, D.G.; Van Itterbeeck, J.; Heetkamp, M.J.; Van Den Brand, H.; Van Loon, J.J.; Van Huis, A. An exploration on greenhouse gas and ammonia production by insect species suitable for animal or human consumption. PLoS ONE 2010, 5, e14445. [CrossRef]

13. Berggren, Å.; Jansson, A.; Low, M. Approaching ecological sustainability in the emerging insects-as-food industry. Trends Ecol. Evol. 2019, 34, 132-138. [CrossRef]

14. Ermolaev, E.; Lalander, C.; Vinnerås, B. Greenhouse gas emissions from small-scale fly larvae composting with Hermetia illucens. Waste Manag. 2019, 96, 65-74. [CrossRef]

15. Makkar, H.P.; Tran, G.; Heuzé, V.; Ankers, P. State-of-the-art on use of insects as animal feed. Anim. Feed Sci. Technol. 2014, 197, 1-33. [CrossRef]

16. Sánchez-Muros, M.J.; Barroso, F.G.; Manzano-Agugliaro, F. Insect meal as renewable source of food for animal feeding: A review. J. Clean. Prod. 2014, 65, 16-27. [CrossRef]

17. Tran, G.; Heuzé, V.; Makkar, H.P.S. Insects in fish diets. Anim. Front. 2015, 5, 37-44.

18. Cappellozza, S.; Leonardi, M.G.; Savoldelli, S.; Carminati, D.; Rizzolo, A.; Cortellino, G.; Terova, G.; Moretto, E.; Badaile, A.; Concheri, G.; et al. A first attempt to produce proteins from insects by means of a circular economy. Animals 2019, 5, 278. [CrossRef] [PubMed]

19. Tschirner, M.; Simon, A. Influence of different growing substrates and processing on the nutrient composition of black soldier fly larvae destined for animal feed. J. Insects Food Feed 2015, 1, 249-259. [CrossRef]

20. Lalander, C.; Diener, S.; Zurbrügg, C.; Vinnerås, B. Effects of feedstock on larval development and process efficiency in waste treatment with black soldier fly (Hermetia illucens). J. Clean. Prod. 2019, 208, $211-219$. [CrossRef]

21. Gustavsson, J.; Cederberg, C.; Sonesson, U.; Van Otterdijk, R.; Meybeck, A. Global Food Losses and Food Waste; FAO: Rome, Italy, 2011; pp. 1-29.

22. Nguyen, T.T.; Tomberlin, J.K.; Vanlaerhoven, S. Influence of resources on Hermetia illucens (Diptera: Stratiomyidae) larval development. J. Med. Entomol. 2013, 50, 898-906. [CrossRef]

23. Surendra, K.C.; Olivier, R.; Tomberlin, J.K.; Jha, R.; Khanal, S.K. Bioconversion of organic wastes into biodiesel and animal feed via insect farming. Renew. Energ. 2016, 98, 197-202. [CrossRef] 
24. Gold, M.; Tomberlin, J.K.; Diener, S.; Zurbrügg, C.; Mathys, A. Decomposition of biowaste macronutrients, microbes, and chemicals in black soldier fly larval treatment: A review. Waste Manag. 2018, 82, 302-318. [CrossRef]

25. Jucker, C.; Erba, D.; Leonardi, M.G.; Lupi, D.; Savoldelli, S. Assessment of Vegetable and Fruit Substrates as Potential Rearing Media for Hermetia illucens (Diptera: Stratiomyidae) Larvae. Environ. Entomol. 2017, 46, 1415-1423. [CrossRef]

26. Ur Rehman, K.; Rehman, A.; Cai, M.; Zheng, L.; Xiao, X.; Somroo, A.A.; Aziz, A.; Wang, H.; Li, W.; Yu, Z.; et al. Conversion of mixtures of dairy manure and soybean curd residue by black soldier fly larvae (Hermetia illucens L.). J. Clean. Prod. 2017, 154, 366-373. [CrossRef]

27. Wang, Y.S.; Shelomi, M. Review of Black Soldier Fly (Hermetia illucens) as Animal Feed and Human Food. Foods 2017, 6, 91. [CrossRef]

28. Nguyen, T.T.; Tomberlin, J.K.; Vanlaerhoven, S. Ability of black soldier fly (Diptera: Stratiomyidae) larvae to recycle food waste. Environ. Entomol. 2015, 44, 406-410. [CrossRef] [PubMed]

29. Čičková, H.; Newton, G.L.; Lacy, R.C.; Kozánek, M. The use of fly larvae for organic waste treatment. Waste Manag. 2015, 35, 68-80. [CrossRef] [PubMed]

30. Commission Regulation (EU). 2017/893 of 24 May 2017 Amending Annexes I and IV to Regulation (EC) No 999/2001 of the European Parliament and of the Council and Annexes X, XIV and XV to Commission Regulation (EU) No 142/2011 as Regards the Provisions on Processed Animal Protein; Commission Regulation: Brussels, Belgium, 2017.

31. Sogari, G.; Amato, M.; Biasato, I.; Chiesa, S.; Gasco, L. The Potential role of insects as feed: A Multi-Perspective Review. Animals 2019, 9, 119. [CrossRef] [PubMed]

32. Manzano-Agugliaro, F.; Sanchez-Muros, M.J.; Barroso, F.G.; Martínez-Sánchez, A.; Rojo, S.; Pérez-Bañón, C. Insects for biodiesel production. Renew. Sustain. Energy Rev. 2012, 16, 3744-3753. [CrossRef]

33. Leong, S.Y.; Kutty, S.R.M.; Malakahmad, A.; Tan, C.K. Feasibility study of biodiesel production using lipids of Hermetia illucens larva fed with organic waste. Waste Manag. 2016, 47, 84-90. [CrossRef]

34. Zheng, L.; Li, Q.; Zhang, J.; Yu, Z. Double the biodiesel yield: Rearing black soldier fly larvae, Hermetia illucens, on solid residual fraction of restaurant waste after grease extraction for biodiesel production. Renew. Energ. 2012, 41, 75-79. [CrossRef]

35. Sangduan, C. Skincare Product Containing Hermetia illucens Extract. U.S. Patent 15/981,689, 13 September 2018.

36. European Statistics. Available online: http://www.fediaf.org//who-we-are/european-statistics.html (accessed on 25 September 2019).

37. Europe Pet Food Market-Analysis of Growth, Trends, and Forecast (2019-2024). Available online: https://www.mordorintelligence.com/industry-reports/pet-food-market-in-europe-industry (accessed on 5 September 2019).

38. Engler, M.; Parry-Jones, R. Opportunity or Threat: The Role of the European Union in Global Wildlife Trade; TRAFFIC Europe: Brussels, Belgium, 2007; ISBN 978-2-930490-04-5.

39. Auliya, M.; Altherr, S.; Ariano-Sanchez, D.; Baard, E.H.; Brown, C.; Brown, R.M.; Cantu, J.C.; Gentile, G.; Gildenhuys, P.; Henningheim, E. Trade in live reptiles, its impact on wild populations, and the role of the European market. Biol. Conserv. 2016, 204, 103-119. [CrossRef]

40. Rumpold, B.A.; Schlüter, O.K. Potential and challenges of insects as an innovative source for food and feed production. Innov. Food Sci. Emerg. Technol. 2013, 17, 1-11. [CrossRef]

41. Lupi, D.; Savoldelli, S.; Leonardi, M.G.; Jucker, C. Feeding in the adult of Hermetia illucens (Diptera Stratiomyidae): Reality or fiction? JEAR 2019, 51, 27-32. [CrossRef]

42. Diener, S.; Zurbrugg, C.; Tockner, K. Conversion of organic material by black soldier fly larvae: Establishing optimal feeding rates. Waste Manag. Res. 2009, 27, 603-610. [CrossRef]

43. Bava, L.; Jucker, C.; Gislon, G.; Lupi, D.; Savoldelli, S.; Zucali, M.; Colombini, S. Rearing of Hermetia illucens on Different Organic By-Products: Influence on Growth, Waste Reduction, and Environmental Impact. Animals 2019, 9, 289. [CrossRef] [PubMed]

44. Bosch, G.; van Zanten, H.H.E.; Zamprogna, A.; Veenenbos, M.; Meijer, N.P.; der Fels-Klerx, H.J.; van Loon, J.J.A. Conversion of organic resources by black soldier fly larvae: Legislation, efficiency and environmental impact. J. Clean. Prod. 2019, 222, 355-363. [CrossRef] 
45. Barragan-Fonseca, K.B.; Dicke, M.; van Loon, J.J. Nutritional value of the black soldier fly (Hermetia illucens L.) and its suitability as animal feed-a review. J. Insects Food Feed 2017, 3, 105-120. [CrossRef]

46. Lock, E.J.; Biancarosa, I.; Gasco, L. Insects as raw materials in compound feed for aquaculture. In Edible Insects in Sustainable Food Systems; Halloran, A., Flore, R., Vantomme, P., Roos, N., Eds.; Springer International Publishing: Cham, Switzerland, 2018; pp. 263-276.

47. Smetana, S.; Palanisamy, M.; Mathys, A.; Heinz, V. Sustainability of insect use for feed and food: Life cycle assessment perspective. J. Clean. Prod. 2016, 137, 741-751. [CrossRef]

48. Salomone, R.; Saija, G.; Mondello, G.; Giannetto, A.; Fasulo, S.; Savastano, D. Environmental impact of food waste bioconversion by insects: Application of life cycle assessment to process using Hermetia illucens. J. Clean. Prod. 2017, 140, 890-905. [CrossRef]

49. Gobbi, P.; Martínez-Sánchez, A.; Rojo, S. The effects of larval diet on adult life-history traits of the black soldier fly, Hermetia illucens (Diptera: Stratiomyidae). Eur. J. Entomol. 2013, 110, 461-468. [CrossRef]

50. Cammack, J.; Tomberlin, J. The impact of diet protein and carbohydrate on select life-history traits of the black soldier fly Hermetia illucens (L.) (Diptera: Stratiomyidae). Insects 2017, 8, 56. [CrossRef]

51. Tomberlin, J.K.; Sheppard, D.C.; Joyce, J.A. Selected life-history traits of black soldier flies (Diptera: Stratiomyidae) reared on three artificial diets. Ann. Entomol. Soc. Am. 2002, 95, 379-386. [CrossRef]

52. Miranda, C.D.; Cammack, J.A.; Tomberlin, J.K. Life-History Traits of the Black Soldier Fly, Hermetia illucens (L.) (Diptera: Stratiomyidae), Reared on Three Manure Types. Animals 2019, 9, 281. [CrossRef]

53. Holmes, L.A.; Vanlaerhoven, S.L.; Tomberlin, J.K. Substrate effects on pupation and adult emergence of Hermetia illucens (Diptera: Stratiomyidae). Environ. Entomol. 2013, 42, 370-374. [CrossRef]

54. Meneguz, M.; Schiavone, A.; Gai, F.; Dama, A.; Lussiana, C.; Renna, M.; Gasco, L. Effect of rearing substrate on growth performance, waste reduction efficiency and chemical composition of black soldier fly (Hermetia illucens) larvae. J. Sci. Food Agric. 2018, 98, 5776-5784. [CrossRef] [PubMed]

55. Oonincx, D.G.; Van Broekhoven, S.; Van Huis, A.; van Loon, J.J. Feed conversion, survival and development, and composition of four insect species on diets composed of food by-products. PLoS ONE 2015, 10, e0144601. [CrossRef] [PubMed]

56. Nakamura, S.; Ichiki, R.T.; Shimoda, M.; Morioka, S. Small-scale rearing of the black soldier fly, Hermetia illucens (Diptera: Stratiomyidae), in the laboratory: Low-cost and year-round rearing. Appl. Entomol. Zool. 2016, 51, 161-166. [CrossRef]

57. Lewandowski, M.; Sznyk, A.; Bednarek, A. Biology and morphometry of Lycoriella ingenua (Diptera: Sciaridae). Biol. Lett. 2004, 41, 41-50.

58. Okolle, J.N.; Ntonifor, N.N. Field ovipositional behavior and laboratory studies on development of Dacus punctatifrons (Diptera: Tephritidae) on tomato. Insect Sci. 2005, 12, 393-398. [CrossRef]

59. Diener, S.; Solano, N.M.S.; Gutiérrez, F.R.; Zurbrügg, C.; Tockner, K. Biological treatment of municipal organic waste using black soldier fly larvae. Waste Biomass Valorization 2011, 2, 357-363. [CrossRef]

60. Nyakeri, E.M.; Ogola, H.J.O.; Ayieko, M.A.; Amimo, F.A. Valorisation of organic waste material: Growth performance of wild black soldier fly larvae (Hermetia illucens) reared on different organic wastes. J. Insects Food Feed 2017, 3, 193-202. [CrossRef]

61. Zhu-Salzman, K.; Shade, R.E.; Koiwa, H.; Salzman, R.A.; Narasimhan, M.; Bressan, R.A.; Hasegawa, P.M.; Murdock, L.L. Carbohydrate Binding and Resistance to proteolysis Control Insecticidal Activity of Griffonia simplicifolia Lectin II. Proc. Natl. Acad. Sci. USA 1998, 95, 123-128. [CrossRef]

62. Permana, A.D.; Putra, J.E.N.R.E. Growth of Black Soldier Fly (Hermetia illucens) Larvae Fed on Spent Coffee Ground. In IOP Conference Series: Earth and Environmental Science; IOP Publishing: Bristol, UK, 2018; Volume 187, p. 012070.

63. Cohen, A.C. Insect Diets: Science and Technology, 2nd ed.; CRC Press: Boca Raton, FL, USA, 2015; pp. 1-473.

64. Tinder, A.C.; Puckett, R.T.; Turner, N.D.; Cammack, J.A.; Tomberlin, J.K. Bioconversion of sorghum and cowpea by black soldier fly (Hermetia illucens (L.) larvae for alternative protein production. J. Insects Food Feed 2017, 3, 121-130. [CrossRef]

65. Spranghers, T.; Ottoboni, M.; Klootwijk, C.; Ovyn, A.; Deboosere, S.; De Meulenaer, B.; Michiels, J.; Eeckhout, M.; De Clercq, P.; De Smet, S. Nutritional composition of black soldier fly (Hermetia illucens) prepupae reared on different organic waste substrates. J. Sci. Food Agric. 2017, 97, 2594-2600. [CrossRef] 
66. Liland, N.S.; Biancarosa, I.; Araujo, P.; Biemans, D.; Bruckner, C.G.; Waagbø, R.; Torstensen, B.E.; Lock, E.J. Modulation of nutrient composition of black soldier fly (Hermetia illucens) larvae by feeding seaweed-enriched media. PLoS ONE 2017, 12, e0183188. [CrossRef] [PubMed]

67. Jensen, K.; Kristensen, T.N.; Heckmann, L.H.; Sørensen, J.G. Breeding and maintaining high-quality insects. In Insects as Food and Feed: From Production to Consumption; van Huis, A., Tomberlin, J.T., Eds.; Academic Publishers: Wageningen, The Netherlands, 2017; pp. 174-198. 